The 3rd World Sustainability

Forum

1-30 November 2013

http://www.sciforum.net/conference/wsf3

\title{
Article
}

\section{EMAS Regulation in Italian Clusters: Investigating the Involvement of Local Stakeholders}

\section{Roberto Merli' ${ }^{1}$, Mara D’Amico², Michele Preziosi ${ }^{1}$ and Ilaria Massa ${ }^{3}$}

1 Roma Tre University, Department of Business Studies, Via Silvio D’Amico, 77, 00145 - Rome, Italy, roberto.merli@uniroma3.it, michele.preziosi@uniroma3.it

2 ISPRA (High Institute for Environmental Protection and Research), Via Vitaliano Brancati 48, 00144 Rome, Italy; mara.damico@isprambiente.it

3 Management Department, "Sapienza” University of Rome, Via del Castro Laurenziano 9, 00161 Rome, Italy; E-Mail: ilariamassa89@gmail.com

* Author to whom correspondence should be addressed; E-Mail: roberto.merli@uniroma3.it; Tel.: +39-0657335813; Fax: +39-06 57335797

Received: 13 September 2013 / Accepted: 28 October 2013 / Published: 01 November 2013

\begin{abstract}
The last revision of the EMAS Regulation encouraged a cluster approach to increase the participation of the organizations and to involve local stakeholders in the sustainability process. Our research activity, conducted by the Department of Business Studies of Roma Tre University and ISPRA (High Institute for Environmental Protection and Research), intends to partially fill the literature gap in the field by investigating the Italian cluster approach for EMAS, characterized by the creation of a cluster Managing Committee (MC) - which can receive an EMAS Cluster Certificate - in order to improve the implementation of the scheme. If in a first phase we investigated the effectiveness of MCs support given to registered EMAS organizations, the main objective of the second step has been to verify the impact of MCs actions on different stakeholders categories in 12 Italian clusters. We present the results of a survey conducted through the distribution of a specifically designed questionnaire on different categories of stakeholders in the considered clusters. The main two goals of the investigation are: to determine the impacts of MCs action in terms of environmental performance enhancements and network creations to improve the cluster competitiveness; to evaluate how the tools offered to cluster organizations have effectively contributed to a widespread knowledge of EMAS and environmental concerns.
\end{abstract}

Keywords: EMAS; regulation; sustainability; Italy; stakeholders; cluster; survey; 


\section{Introduction}

The sustainability of production is a main issue for the international community, which agrees with the need to implement transnational coordination of environmental policies through sustainable projects that involve the stakeholders at the local level (think globally, act locally).

SMEs account for more than $70 \%$ of the polluting emissions in Europe. In Italy, industrial clusters are over 150 and they represent an essential part of the national productive structure, especially in the manufacturing sector. In fact, this productive area is responsible for 25,6\% of total national exports. These areas are characterized by a dense network involving different categories of stakeholders due to several factors such as geographical proximity, supply chain integration, same specialization. These features make the Italian clusters ideal places to implement environmental management policies coordinated at local level.

In Europe about 3.700 organizations have EMAS registered sites, and Italy is the second country for the diffusion of the scheme with over 1.000 organizations.

In order to overcome economic difficulties for SMEs, EU institutions have encouraged a cluster-based approach to implement EMAS. Italy has collected this orientation, and since 2005 the EMAS Competent Body issued two position papers to apply the Scheme in clusters.

The priority was to involve all local stakeholders in promoting a shared path for sustainability. In this perspective a Managing Committee (MC) has been identified to coordinate the activities and introduce a good practice model for the environmental management of the area. The commitment and tangible results are recognized by the Italian Competent Body through the release of a specific EMAS cluster certificate to the Managing Committee that meets EMAS scheme requirements. In particular, the MC has to develop an Environmental Policy, an Environmental Review, an Environmental Program and some Environmental performance indicators. Currently twelve Italian clusters have obtained the EMAS Certificate.

\section{Literature review}

The scientific community has recognized the existence of a strong interconnection between enterprises and their environment. Enterprises have to deal with different categories of stakeholders to maintain their success [1]. These categories can be identified on the basis of the relationship they have with the companies. Clarkson introduced a classification criterion which distinguished stakeholders in primary and secondary. The first group is essential to the company's survival (e.g. shareholders and employees), the second is able to influence companies' decisions, but it cannot compromise directly their existence[2]. Companies must effectively manage various pressure groups adopting strategies to respond to diversified needs [3]. Stakeholder theory has evolved from a purely business and economic to a multi-objective approach acquainting companies also with social and environmental issues [4]. Growing awareness of public institutions, citizens and consumers towards environmental sustainability[5] has significantly increased the pressure on companies pushing to reduce their negative environmental impacts [6,7]. The

pressure imposed by external stakeholders as Public Authorities with strict environmental regulation has forced companies to adopt environmental practices [8]. Furthermore, consumers demand products and 
services aligned with societal and environmental values [9]. In order to meet effectively these issues and to remain competitive on the markets, companies should implement environmentally proactive practices such as design for environment, Life Cycle Analysis, Environmental Management System (EMS) [10]. The participatory decision-making mechanisms for environmental matters were eventually incorporated into national and international policies [11]. The creation of partnerships between public and private "entities" helped to create new form of global governance that performed both with multilateral and international agreements, which involved different stakeholder groups in promoting local development practices [12]. Participation mechanisms have been studied which were focused on methodologies for stakeholders involvement $[13,14]$. Agenda 21 is the main international reference for the implementation of sustainable development through the involvement of local groups of interest. There are several studies about implementing instruments available to local government to assess the strengths and weaknesses point and provide good practices [15-19].

The growing interest of both internal and external stakeholders in companies' activities has led many organizations to adopt EMS certification. The adoption of these tools not only allows negative impacts reduction but it also facilitates the improvement of organizations internal management [20]. Moreover, self-regulation allows companies to run specific procedures for environmental improvement on a voluntary basis. That enables enterprises to adopt flexible strategies to effectively respond to market needs and to increase their competitiveness [21]. The main references for the EMS are ISO 14001 Certification and the European EMAS Regulation (Reg. EC n. 1221/2009). There have been several studies on EMAS, its benefits and its costs. The main benefits are the improvement of legal compliance and the enhancement of companies' reputation. More benefits are related to reduced costs for raw materials, waste management and energy consumption [22,23]. Costs for implementing EMS are high. These are the main obstacle to their diffusion, especially among Small and Medium-sized Enterprises (SMEs), which account for the majority of European enterprises. Empirical studies found that costs in terms of economic resources, time and skills required for implementing EMAS were identified as the main barriers by SMEs [24].

Industrial clusters are areas characterized by a high concentration of SMEs which are specialized in the same economic sector and located in a shared socio-economic system [25]. Many authors have studied the cooperative and the interaction mechanisms which are present within these areas [26]. The competitive factors of these systems consist in the existence of links between local organizations and the interdependence between the companies which share the same production process [27]. Innovation and continuous improvement of environmental performance processes within a cluster are similar to processes implemented within companies. In both cases it is essential to identify the objectives based on the needs of key stakeholders [28].

The attention to stakeholder involvement makes EMAS the ideal tool to integrate sustainable development aims in local policies. For this reason the European Community and Italian institutions have encouraged a territorial approach to the scheme. The goal of these projects is to implement EMS methodology in a cluster, that will offer the possibility to the various parties the opportunity to cooperate to reduce the level of environmental criticality. Tuscany Region has been the first mover and it has implemented several projects. For example, the PIONEER project in the paper cluster in Capannori, the IMAGE project in the textile cluster in Santa Croce sull'Arno, and the leather and footwear cluster in Prato: those cases have 
been subject of numerous empirical studies [29,30]. Italian Competent Body for EMAS has set up a special award named "EMAS Cluster Certificate" which is grated to cluster Managing Committees which implemented the scheme at local level. The implementation of this peculiar Italian experience has been investigated by ISPRA [31].

\section{International Community}

In 1987 the Brundtland Report "Our Common Future" formalized the concept of Sustainable Development. The Report results have been the starting point for the United Nations World Conference on "Environment and Development" held in Rio de Janeiro in 1992. The primary objective was to identify common solutions to implement sustainable growth on a global scale. The complex and dynamic nature of environmental problems required the adoption of a flexible and transparent decision-making process which could incorporate instances of different social groups into sustainable development policies [11].

During the Conference it was draught an action plan known as Agenda 21. Agenda 21 contained guidelines to realize multi-level development policies from the international level to a local one. Moreover, the document defined general issues about increasing the involvement of all categories of social actors in order to promote intra-sector strategies for economic development and environmental protection. There was firms' belief that to solve global problems such as the environmental one, it was necessary to carry out a bottom-up approach, involving local communities in projects to diffuse territorial environmental protection among private and public organizations.

In the business world environmental management tools have been introduced among which there were the voluntary instruments as environmental management systems: [The industry must establish environmental management systems, environmental audit systems on production and sites production, with the aim for identify where it is required the installation of systems to reduce pollution], (Agenda 21 - chapter 20 Environmentally sound management of hazardous wastes, Including prevention of illegal international traffic in Hazardous wastes).

The role of local institutions in facilitating the access to these instruments for Small and Medium Enterprises and the importance of cooperation among companies, research centres and universities has been particularly stressed [... trade and industry, including transnational corporations, should increase research and development of environmentally sound technologies and environmental management systems, in collaboration with universities and scientific institutes ...], (Agenda 21 - chapter 30 Strengthening the role of business and industry).

As established in Chapter 28 "Local Authorities' Initiatives in Support of Agenda 21", the implementation of the participation and co-operation between public authorities and local stakeholders is essential to resolve of Agenda 21 initiatives (Agenda 21 - chapter 28 Local Authorities' Initiatives In Support Of Agenda 21). In fact, the implementation of decentralized actions has a critical role in local sustainability programs.

The aim was to identify proper tools and mechanisms to implement the involvement of local stakeholders in processes of participatory development. The solution was found in the adoption within 1996 of Local Agenda 21 by local authorities of participating countries. 
During the Johannesburg Summit "Type II" agreements were approved, aimed to encourage the involvement of non-institutional actors. The agreements introduced substantial changes in decisionmaking approach in order to facilitate network creation and to enable interested parties to cooperate to promote activities linked to the Summit objectives [16]. Multi-sectorial networks were created, as organizational systems based on voluntary cooperation among public, economic and civil parties. The network was governed by a non-hierarchical decision-making structure which deals with public interest issues [11] reducing the participation gap.

Over the years, several studies have demonstrated how the ability to involve the different categories of local stakeholders is crucial to improve significantly the quality of regional environment [18]. In 2004 it a survey has been carried out which showed that in Italy the adoption of Local Agenda 21 had a considerable spread, targeting more than 800 Local Authorities. More than 360 Public Institutions have been interviewed and the majority of them registered as a positive experience the introduction of voluntary environmental management mechanisms.

\section{European Community}

With the adoption of the Fifth Environmental Action Program (5EAP) European institutions fully recognized the importance of implementing sustainable development models on a local level, involving all the stakeholders in the area. This important document traced European guidelines in the field of environmental policies. It introduced the subsidiarity principle, according to which environmental programs must be completed at the most appropriate territorial level and the local actors must act [maximizing the participation of all sectors of society ... by the public, the private and public enterprises, the general public (as both individual citizens and consumers)] (OJ n.C138/12 from 17.5.93)

Beside the subsidiarity principle also the broader concept of co-responsibility among stakeholders was introduced: [... If the goal of the ' 80 s was the completion of the internal market, one of the most important objectives of the '90s would be the reconciliation of environment and development concepts [...] through the involvement at all levels, political and professional ones, and the participation of the whole community] (OJ n.C138/12 from 17.5.93).

The new strategy replaced the passive and "planned-centered" [13] approach, where the attention was focused just on results, with an active participatory approach. The so-called "people-centered" [13] approach consists in achieving the desired outcome, encouraging the contribution of different social actors, increasing their empowerment and the confidence in the actions taken.

New tools have been proposed to implement the new approach, which included environmental management systems and EMAS Regulation to disseminate good practices and voluntary commitments among companies.

Also in the Sixth Environmental Action Programme the importance of promoting voluntary instruments, and especially EMAS registration, was reaffirmed. It was underlined the importance to simplify Registration for Small and Medium Enterprises (SMEs) which do not have the resources due to the small size (OJ n. L 242 from 10.09.2002). For this reason it urged local authorities measures to increase 
companies awareness on environmental issues and called for greater cooperation for the improvement of environmental performance(OJ n. L 242 from 10.09.2002).

The program stressed the importance of citizens and consumers role. Citizens environmental information/education is a critical factor: [citizens need to know and understand the issues in question, the necessary solutions and the contribution they can make](OJ n. L 242 from 10.09.2002).

The main groups of interest should cooperate to create simple tools to inform about the environmental impact of local production available and to increase the knowledge on voluntary engagement tools such as EMAS.

These systems were identified as fundamental in spreading environmental awareness in the business world. The third edition of the EMAS Regulation n.1221/2009 incorporated the 5th and the 6th EAP guidance and it encourages Member States to facilitate access to this tool. Full prominence has been given to the creation of synthetic mechanisms to report to the public environmental performances through the inclusion of "key performance indicators" in the Environmental Statement.

Furthermore it is related EMAS to a specific territorial context implementing the scheme at cluster level. This strategy overcomes problems of small enterprises lack of resources and it tackles environmental challenges through assets pool thanks to high concentration of SMEs at local level.

So the "Cluster approach" was developed, where cluster is a "group of firms, related economic actors and institutions that are located close to each other. The group has reached a sufficient scale to develop specialized expertise, services, resources, suppliers and skills" (COM(2008) n.652).

The approach fully incorporates the concepts arose in Agenda 21 and contained in the EAP, according to which the implementation of sustainable development policies need the involvement of local communities.

Since the 2005, the Italian EMAS Committee and ISPRA identified the possibility of extending the application of EMAS scheme at a cluster level. The Competent Body suggested the creation of participatory governance models which include not only enterprises but also public authorities and private citizens.

EMAS cluster approach well suited the Italian production structure characterized by a high concentration of SMEs and where the main obstacle to the registration it is the scarcity of financial resources due to the small size of enterprises. Cooperation among different territorial entities will overcome this problem by facilitating the spread of the Regulation and a new cluster approach to environmental management systems.

\section{Clusters in Italian economy}

Italian industrial system is based on small business: ISTAT data on industry and services census reveal that in 2009 only $0,8 \%$ of companies have more than 250 employees and $99,4 \%$ have less than 50 workers.

The average size of Italian firms is about $60 \%$ compared to the average of other European Union countries. $95 \%$ of companies have less than 10 employees with a weight of $47 \%$ compared to EU average 
which is somewhere between 20-30\% [27]. The widespread presence of industrial clusters differentiates the Italian production system from other countries with advanced level of development [32].

Alfred Marshall theorized the first concept of Cluster (1842-1924). Giacomo Becattini adapted the concept to Italy by defining cluster as "socio-territorial entity characterized by the active cooperation between a community of people and industrial enterprises in a circumscribed, naturalistically and historically determined area" [25].

The distinctive features of an industrial cluster are the presence of a local community and an institutional system based on a fairly homogeneous population of firms specialized in one prevailing industrial sector. Each firm is specialized in a single step or few steps of the production process of the cluster that is configured as a vertically integrated supply chain or sector. In relation to these characteristics, the cluster presents both characteristic of a single company and an entire industry [32].

Italian clusters present a high concentration of specialized SMEs, they often have a high level of interdependence of production processes and they also have a strong integration with local socioeconomic environment. Another peculiar aspect is the combination of competition and cooperation among the entities in the cluster [32].

In Italy clusters were formally recognised the 5th October 1991 with law n. 317 (art. 36). Gradually, law n.140/99 has simplified the criteria for clusters identification by introducing a new definition. There were introduced "Local Production System" (LPS) to identify productive contexts which present a high concentration of SMEs (GU n.117 from 21.5.1999). LPS must possess certain characteristics to be considered an industrial cluster: high concentration of industrial enterprises; highly specialized production systems of firms; companies that co-operate together to develop supply chains; homogeneous production contexts [33].

In 2006 the Finance Act made reference to "industrial cluster" as "productive cluster". The productive clusters are defined as [free business combined territorially and functionally aimed for enhancing development of the area and sectors, to improve organizations productive efficiency, according to the principles of vertical and horizontal subsidiarity, also identifying ways of working with business associations] (GU n.302 from 29.12.2005). The concept of cluster as a precise geographical area which is specialized in a unique sector is exceeded by the possibility that in a cluster are operating different industries (both manufacturing and services).

Italian main productive sectors are: clothing, furniture, mechanical, food and beverage [34].

In 2001 the survey carried out by ISTAT named "Eighth general census on the industry and services" identified 686 Local Labour Systems (LLS). According to the survey 156 LLS are identified as industrial clusters belonging to the four main areas.

In those industrial clusters SMEs represent 90,7\% of employment and 77,6\% of exports [32].

In the clusters are employed over 4,9 million people, which represent over $25,4 \%$ of the entire country workforce. In particular over 1,9 million people are employed in manufacturing clusters which correspond to $39,3 \%$ of total Italian manufacturing employment [26].

ISTAT survey noticed that the industrial clusters are equally distributed among regions in Centre, (49) North East (42) and North West (39) of Italy, while much less industrial clusters are in the South regions(26). 
In 2013 the "Fourth Report of the Observatory Italian Clusters" has been published, which represent the most recent survey on economic trends in the clusters. According to the study carried out on a sample of 101 clusters, during the last two years there was an accentuation of the recessionary cycle, stagnating demand and a slowdown in trade flows. In the clusters surveyed there are 274.055 companies, the $4,5 \%$ of Italian firms. They account for $28,1 \%$ of total manufacturing economy, they realized to $6,9 \%$ ( $€ 74$ billion) of added value of Italian economy and they account for the $25,6 \%$ of total exports.

According to ISTAT (2010), clusters supply chains are formed $98,4 \%$ of small companies. The $86,6 \%$ of them have at most 9 employees. Medium-sized enterprises, which have from 50 to 249 employees, are equal to $1,4 \%$, but the manufacturing ones $(2,812)$ constitute the $32 \%$ of the total Italian mid-sized manufacturers. The economic crisis has also affected industrial clusters: between 2010 and 2011, 51\% of SMEs decreased the sales and the $26 \%$ has dismissed employees. The Research Department of the Intesa San Paolo Group forecasted that in 2013 it should follow a light recovery in revenues $(+1,1 \%)$ and a greater recovery in 2014 ( $+4 \%$ turnover).

\section{EMAS cluster approach}

\subsection{First experiences}

In the late nineties the first environmental management experiences on a regional scale started. At the time the first version of the EMAS Regulation was in force (EC Reg n.1836/1993), which did not make any reference to the possibility of taking advantage of a territorial aggregation for the application of the Scheme [35]. The chemical hub in Gendorf in Germany was one of the most significant European experiment. In 1998 it has been created an integrated environmental management system which was compatible with the individual EMAS scheme registered companies. There were developed common documents such as Environmental Policy, the Environmental Programs and the Environmental Statement of the entire area [36].

A year later in the Italian production centre of Bayer Filago some enterprises signed an agreement to elect an Intercompany Environmental Committee with the task of developing and monitoring the implementation of a Common Environment Programme. These pioneering experiences were based on a new interpretation of the industrial site, which was configured as an expanded site, or as the sum of industrial sites involved in the area. The evidence of good results of these projects led to the adoption of EMAS II Regulation (EC Reg n.761/2001), which emphasized the importance of collaboration between heterogeneous subjects in the territory for the uptake of the Scheme [35].

\subsection{EMAS II}

The EC Regulation n.761/2001 (EMAS II) emphasized the importance of participation of SMEs in EMAS. Article 11 has highlighted the role of the Member States in facilitating the registration process or renewal of EMAS to SMEs and organizations [... concentrated in well defined geographical areas ...]. It was referred both public actors, such as Local Authorities, and external actors as Chambers of Commerce, Industry Associations and/or category, as well as any group of interest in the area. 
Intermediate institutions has therefore the role of intermediation and stimulus to the growth of environmental management systems. SMEs can use information generated by these entities to implement EMAS establishing of environmental programs, targets and objectives needed [35].

Even though it is not explicitly mentioned in the Regulation, SMEs concentrated in well defined geographical areas can be compared to Italian industrial clusters. For this reason, the facilitation of EMAS diffusion by a systemic and collaborative approach assumes great importance for Italy.

After the adoption of the Regulations are followed some European acts to clarify the meaning and scope of article 11: EC Decision n.681/2001, the EC Recommendation n.680/2001 and the EC Recommendation n.532/2003.

EC Decision n.681/2001 Annex I dispositions have provided valuable insights about the operational definition of entities that could be EMAS registered. Step 6 disposed that independent organizations located in a limited area can pool resources to register as one common organization. Participant organizations in order to get a common registration should implement policies and procedures for the management aspects and significant environmental impacts by setting common goals, targets and corrective actions. The cooperation is based on the exchange of experiences and on the identification of environmental aspects and impacts, in order to develop joint environmental policies and programs. There are also provided other hints as the use of the same consultant and environmental verifier services, the use of the same infrastructure for the management of impacts and the participation in local environmental projects. In order to facilitate access to EMAS for SMEs, local authorities and intermediate bodies (Article 11 EMAS II) should draft environmental review of the entire region and create a Regional environment Programme to improve the environmental performance of the whole reference area.

EC Recommendation n.680/2001 in Annex IV confirmed the growing European orientation in promoting the involvement of SMEs and local intermediary parties. In the annex is allowed the partnership between two or more micro businesses to undertake audit and analysis of environmental management. The aim was to save time and resources of such these entities overcoming their structural difficulties (human, financial and technical scarcity). The importance of intermediate institutions in supporting SMEs was also stressed, on the path that leads to implement an environmental management system certificate: for this reason audits could be carried out by Chambers of commerce, trade associations and local organizations of SMEs. The EC Recommendation n.532/2003 on the application of EMAS in relation to the choice and use of environmental performance indicators is a further confirmation of the orientation to a territorial approach.

In Annex I it was required to develop common indicators in order to obtain comparable homogeneous data for all organizations from the same sector. In this way organizations could refer to common standards developed by trade associations, professional associations, local authorities, national or regional institutions. The use of common indicators has the advantage of standardize the environmental performance monitoring of the whole area and decrease organizations costs. Organizations can lighten the burden necessary to implement a environmental management system, using tools provided by intermediary institutions in the area. 


\subsection{Cluster measures in Regulation EMAS III}

EMAS Regulation III (2009) inserted the Italian cluster standard in art.37. According to the norm, Member States have to encourage all third parties (such as local authorities in partnership with the industrial associations, chambers of commerce and other interested parties) to provide assistance to organizations in implementing environmental management system defined by EMAS.

Cooperation between public and private local entities should pursue the reduction of registration costs for SMEs. There should be encouraged synergies among groups of interest to adopt "cluster-based approach", and a "step by step approach".

The "cluster approach" is based on a management system created to help groups of organizations which belong to the same sector of activity or, alternatively, localized in the same area. The "step by step" approach aims for increasing the number of records of individual organizations planning a path that will gradually increase the attention of organizations and local stakeholders towards environmental protection.

\section{Italian EMAS Cluster Certificate}

Numerous initiatives have been promoted to apply EMAS enhancing local development factors and leveraging on synergies and cooperation between SMEs.

Tuscany Region has been the first in implementing experimental process to define an institutionally recognized model for applying EMAS in clusters. In 2001 three Tuscan clusters received EMAS recognition for their common efforts in eco-efficiency.

With the support of the Institute for Energy and Environmental Economics and Policy (IEFE), Tuscany created a project to develop innovative elements of the EMAS Regulation, in order to facilitate its application to Italian industrial clusters. There have been developed some of the current cluster-based approach of the EMAS Regulation III, f.e. the PIONEER project (Paper Industry Operating in Network, an experiment for EMAS revision) and the ESEMPLA Project.

In 2003 Tuscany Region published operational guidelines about the testing of EMAS in clusters. After two years, when the experiments were completed the Region adopted a document called "EMAS for the industrial clusters: the Tuscan model and lines application guide" [37].

\subsection{Eco-label and Eco-audit Committee first position and EMAS cluster certificate}

In 2005, the Committee published a specific position about the application of the EMAS Regulation in specific areas called Homogeneous Production Areas (HPA) (Position Paper - 28.01.2005).

The position allowed the possibility of applying the EMAS Regulation to HPA, which were defined as [the union of one or more industrial zones in which there are identifiable specific business sectors or parts of supply chains ...]. The choice to refer the position to HPA was due to the fact that they are an important part of the Italian production [38].

The main objective was to encourage the establishment representative bodies able to implement EMAS registration diffusion to individual organizations set in the HPA. There were introduced two ways to reward the effort of EMAS HPA implementation. The national Competent Body could registered a single 
organization which coordinated the cluster application of the scheme. Otherwise, it could realise a Certificate to the HPA Managing Committee.

This entity is often made up of both public (local authorities such as municipalities, provinces and regions) and private organizations (chambers of commerce, business associations, trade unions).

The Managing Committee (MC) is responsible for the creation of the necessary synergies for accession to the Scheme of companies and to coordinate the HPA activities. In particular it works to remove all the burdens that the SMEs could not afford individually. In fact, MC tasks are to provide methodological support to individual organizations to register EMAS and to implement [a comprehensive approach to improve the environmental quality of the territory ...] [38].

The position indicates the requirements for issuing the single registration or the certificate. Requirements consist in drafting Environmental Policy, Environmental Analysis, Environmental Program and in providing internal and external communications to local stakeholders. The position also identified simplification tools that should be provide to local organizations by the MC.

\subsection{New Committee position}

EMAS III Regulation inspired the Committee for the Eco-label and Eco-audit, with the support of ISPRA, the drafting of a new position (22.2.2011) on "application of the EMAS Regulation developed in the clusters". The new position replaced the one adopted in 2006.

It has been introduced a new framework for encouraging organizations located in Italian districts to apply EMAS. The new position introduced new elements outcome of the positive experiences encountered following the issuance of the first position on the HPA.

Compared to the previous position, it has been stressed not only the registration of single organizations, but also the possibility to involve all stakeholders to improve clusters environmental performances and to activate a transparent and efficient communication with the public. The new dispositions rose from the awareness that commitment of just few firms would not be sufficient to obtain a significant environmental improvement of the whole area [39].

According to the innovations introduced by EMAS III, environmental performance key indicators are the fundamental elements to successfully implement the EMS. In fact, the regulation required that MC must use key indicators to monitor the environmental performances of the area. MC must also hire indicators on stakeholders communication.

EMAS cluster approach is an innovative way to promote local sustainable development policies. It provides essential support to single organizations which want to pursue a path of sustainable management of their activities. In fact, the joint application of simplification procedures proposed could remove many obstacles to SMEs Registration.

In addition, the new approach has the prerequisites to contribute effectively to sustainable development of the territory.

The orientation assigned to MC a task of primary importance in guiding local environmental policies. It is thus set up an "extended governance in which choices emerge as a result of a complex process shared by different actors". That encourages the collaboration of public and private entities. Compared to other local 
development processes such as Local Agenda 21, the peculiarity of EMAS certificate is the reference to a specific EMS already used by single organizations, which promotes also the involvement of public institutions [38].

\section{Survey investigation on EMAS applied in Italian clusters}

\subsection{Goal of the survey}

The survey aimed at investigate the actions implemented by MCs which have obtained EMAS Cluster Certificate. The analyzed aspects refer to the main tasks that the position attributes to MCs. The survey investigated the effectiveness in:

- Improving cluster image

- Improving cluster environmental performance

- Improving relationship with local stakeholders

- Improving the awareness on EMAS Cluster certificate

- Helping local organizations in achieving EMAS registration

The impact of these actions was calculated on the base of the strengths and weaknesses of MC actions. In addition, it has been analyzed the level of effectiveness perceived by different categories of local stakeholders. For the analysis there have been selected as respondents both members of MCs and external parties. The interviewed stakeholders' categories are:

- $\mathrm{MC}$

- Chambers of Commerce

- Municipalities

- $\quad$ ISO Certified Organizations

- EMAS Registered Organizations

\subsection{Methodology}

The respondents belong to the stakeholders' categories settled in clusters area which have obtained EMAS Cluster Certificate. Currently in Italy there are $12 \mathrm{MCs}$ which has been issued a Certificate. The investigation took into account 9 clusters that certified on the $1^{\text {st }}$ of November 2012, (Table 1).

Table 1. Italian Cluster with EMAS Cluster Certificate

\begin{tabular}{|l|c|c|}
\hline Cluster & Release date & Prevalent NACE Code* \\
\hline HPA of Ravenna & July 2006 & $19-20-22-23-25-35-38$ \\
\hline Furniture cluster of Livenza & July 2006 & 31 \\
\hline Tanning cluster of Vicenza area & July 2007 & 15 \\
\hline Paper cluster of Capannori & September 2008 & $17-20-28$ \\
\hline
\end{tabular}




\begin{tabular}{|l|c|c|}
\hline Tanning cluster of Solofra & June 2009 & 15 \\
\hline Touristic system of the Polesine area & June 2009 & 15 \\
\hline Tuscany tanning cluster & December 2010 \\
\hline Paper cluster of the Frosinone province & March 2011 & 17 \\
\hline Chemical-pharmaceutical cluster of Latina & May 2012 & 13 \\
\hline Clothing cluster of Empoli & December 2012 & $13-14-15$ \\
\hline Footwear cluster of Lucca & December 2012 & 15 \\
\hline Textile cluster of Prato & December 2012 & $13-14$ \\
\hline
\end{tabular}

* Reference: EC Regulation n.1893(2006) "that defines the statistical classification of economic activities NACE Revision 2" that amendes Regulation EEC n.3037(1990).

Respondents were selected using the official documents produced by clusters MCs. For each cluster the specific geographical area has been identified within which select the reference population.

Two categories of companies were selected, using the prevalent NACE codes of clusters. In order to select EMAS registered organizations it has been used ISPRA database, while to select ISO 14001 certified organizations it has been used the database provided by ACCREDIA (Italian National Accreditation Body).

The survey has been carried out using the feedback of five different qualitative questionnaires with multiple-choice questions. It has been used a modified Likert Scale, ranging from 1 to 6 . (with 1 corresponding to not appreciated/not difficult/not important and 6 corresponding to very appreciated/very difficult/very important).

In each questionnaire, questions were structured into several sections, (Table 2).

Table 2. Questionnaires structure

\begin{tabular}{|l|l|}
\hline Stakeholder category & \multicolumn{1}{c|}{ Sections structure } \\
\hline \multirow{3}{*}{ MC } & - Section 1: Interest and participation of the organizations \\
& - Section 2: Operative modalities \\
& - Section 3: Role of the MC \\
\hline \multirow{3}{*}{ Municipalities } & - Section 1: Policy and investments to promote local sustainability \\
& - Section 2: EMAS Cluster Certificate \\
\hline \multirow{2}{*}{ Chambers of Commerce } & - Section 3: EMAS registration \\
\hline \multirow{3}{*}{ EMAS Organizations } & - Section 1: Policy and investments to promote local sustainability \\
& - Section 2: MC and cluster certification \\
\hline \multirow{2}{*}{ ISO 14001 Organizations } & - Section 1: Information on the organizations \\
& - Section 2: EMAS assessment \\
& - Section 3: Relationship among organizations and MC \\
\hline
\end{tabular}


Respondents were contacted by phone and then they were invited via email to complete the questionnaires available on an online platform. Table 3 shows the number of referred population for each category and the respective percentages of respondents.

\subsection{Population and Sample}

In the beginning the main demographic characteristics of the cluster were identified, then the composition and the main areas of intervention of the MCs. (Table 3).

Table 3. Main characteristics of the clusters with an EMAS certificate

\begin{tabular}{|c|c|c|c|c|c|c|}
\hline Year & Cluster & Firms & Municipalities & EMAS-reg. & $\begin{array}{c}\text { ISO } \\
14001\end{array}$ & MC Composition \\
\hline 2006 & HPA of Ravenna & 20 & 1 & 9 & 32 & Local authorities \\
\hline 2006 & $\begin{array}{l}\text { Furniture cluster of } \\
\text { Livenza }\end{array}$ & 800 & 18 & 4 & 8 & Firms, local authorities \\
\hline 2007 & $\begin{array}{l}\text { Tanning cluster of the } \\
\text { Vicenza area }\end{array}$ & 813 & 17 & 0 & 28 & Local authorities \\
\hline 2008 & $\begin{array}{l}\text { Paper cluster of } \\
\text { Capannori }\end{array}$ & 339 & 13 & 13 & 10 & $\begin{array}{l}\text { Local authorities, } \\
\text { chamber of commerce, } \\
\text { industrial association, } \\
\text { trade unions }\end{array}$ \\
\hline 2009 & $\begin{array}{l}\text { Tanning cluster of } \\
\text { Solofra }\end{array}$ & 400 & 4 & 0 & 9 & $\begin{array}{l}\text { Local authorities, } \\
\text { chamber of commerce, } \\
\text { industrial association, } \\
\text { trade unions }\end{array}$ \\
\hline 2009 & $\begin{array}{l}\text { Touristic system of } \\
\text { the Polesine area }\end{array}$ & 1,340 & 14 & 1 & 4 & $\begin{array}{l}\text { Local authorities, } \\
\text { chamber of commerce, } \\
\text { park authority }\end{array}$ \\
\hline 2010 & Tuscan tanning cluster & 8185 & 7 & 3 & 17 & $\begin{array}{l}\text { Local authorities, tanning } \\
\text { consortium association }\end{array}$ \\
\hline 2011 & $\begin{array}{l}\text { Paper cluster of } \\
\text { Frosinone province }\end{array}$ & 74 & 16 & 0 & 1 & $\begin{array}{l}\text { Local authorities, } \\
\text { University, chamber of } \\
\text { commerce, trade unions, } \\
\text { regional environmental } \\
\text { agency }\end{array}$ \\
\hline 2012 & $\begin{array}{l}\text { Chemical - } \\
\text { Pharmaceutical cluster } \\
\text { of Latina }\end{array}$ & 120 & 6 & & 6 & $\begin{array}{l}\text { Local authorities, } \\
\text { chamber of commerce, } \\
\text { industrial association }\end{array}$ \\
\hline
\end{tabular}


Table 4 shows the percentage of respondents for each category.

Table 4. Population

\begin{tabular}{|l|c|c|c|c|c|}
\hline Category & $\begin{array}{c}\text { Managing } \\
\text { Committees }\end{array}$ & $\begin{array}{c}\text { EMAS } \\
\text { Organizations }\end{array}$ & $\begin{array}{c}\text { ISO 14001 } \\
\text { Organizations }\end{array}$ & Municipalities & $\begin{array}{c}\text { Chambers of } \\
\text { Commerce }\end{array}$ \\
\hline Population & 9 & 35 & 67 & 67 & 9 \\
\hline Respondents & $89 \%$ & $66 \%$ & $54 \%$ & $30 \%$ & $78 \%$ \\
\hline
\end{tabular}

\subsection{Managing Committees survey findings}

It has been asked to MCs to express an opinion about improvements obtained thanks to the activities carried out in clusters. In particular, the judgment was required about issues identified according to the tasks assigned by the Position Paper to the MC (Table 5).

Table 5. Improvements obtained thanks to the EMAS certificate

\begin{tabular}{|l|c|}
\hline Improved aspect & $\begin{array}{c}\text { Mean value } \\
\text { (ranging from 1 to 6) }\end{array}$ \\
\hline Involvement of local stakeholders & 4,38 \\
\hline Environmental performance of the cluster & 4,25 \\
\hline Involvement of the organizations regarding sustainability & 3,50 \\
\hline Increase of EMAS-registered organizations & 2,88 \\
\hline $\begin{array}{l}\text { Ability of the organizations of the cluster to obtain } \\
\text { bureaucratic/administrative simplifications }\end{array}$ & 2,63 \\
\hline Ability of the cluster to attract investments & 2,50 \\
\hline Overall mean & $\mathbf{3 , 3 5}$ \\
\hline
\end{tabular}

According to MCs' perceptions, EMAS certificate increased the ability to involve local stakeholders and it improved cluster's environmental performance. Less positive effects have been observed concerning new EMAS registrations, investments attraction capability and bureaucratic/administrative simplifications.

It was then asked to MCs what were the main difficulties encountered in carrying out their activities. The main difficulties were about the diffusion of EMAS registrations and the financial support to organizations in order to obtain EMAS (Table 6).

Table 6. Main difficulties identified

\begin{tabular}{|l|c|}
\hline Difficulty & $\begin{array}{c}\text { Mean value } \\
\text { (ranging from 1 to 6) }\end{array}$ \\
\hline Involvement of organizations in order to start the EMAS registration path & 4,63 \\
\hline
\end{tabular}




\begin{tabular}{|l|c|}
\hline Funding supply for organizations & 4,57 \\
\hline Support in terms of human resources for organizations & 4,14 \\
\hline Sharing of operative tools with the organizations & 3,57 \\
\hline Communication with the organizations & 3,00 \\
\hline Communication with the stakeholders of the cluster & 3,00 \\
\hline Overall mean & $\mathbf{3 , 8 2}$ \\
\hline
\end{tabular}

\subsection{Local stakeholders survey findings}

Other categories of stakeholders were questioned about the efficacy of MCs in performing their tasks. In particular, they were further asked to give opinion on the effectiveness of the actions the carried out in order to:

- Improve environmental performances

- Improve the cluster image

- Support economically local organizations

- Create a network among local organizations

There have been compared perceptions of each category of local stakeholders.

Table 7 and Table 8 show the main positive aspects identified by the respondents. The investigated aspects relate to a positive perception about the improvement of environmental performance and image of the cluster.

Table 7. Improvement of Clusters environmental performances

\begin{tabular}{|l|c|}
\hline Improvement of Clusters environmental performances & Mean value \\
\hline Municipalities & 4,11 \\
\hline EMAS Organizations & 4,05 \\
\hline Chambers of Commerce & 3,57 \\
\hline ISO 14001 Organizations & 3,00 \\
\hline Overall mean & $\mathbf{3 , 6 8}$ \\
\hline
\end{tabular}

According to respondents, slight improvement is related to the ability of the MCs in reducing clusters environmental impacts.

In particular, just EMAS organizations and municipalities believed that actions taken were effective.

Table 8. Improvement of Clusters image

\begin{tabular}{|l|c|}
\hline Improvement of Clusters image & Mean value \\
\hline Chambers of Commerce & 4,43 \\
\hline
\end{tabular}




\begin{tabular}{|l|c|}
\hline EMAS Organizations & 4,30 \\
\hline Municipalities & 4,28 \\
\hline ISO 14001 Organizations & 3,67 \\
\hline Overall mean & $\mathbf{4 , 1 7}$ \\
\hline
\end{tabular}

Local authorities and external parties pointed out as the most positive aspect the improvement of cluster image with an average score greater than 4. In Table 9 are instead reported the actions of MCs perceived as less effective.

Table 9 Financial support for EMAS registration

\begin{tabular}{|l|c|}
\hline Financial support for EMAS registration & Mean value \\
\hline Chambers of Commerce & 3,57 \\
\hline ISO 14001 Organizations & 3,10 \\
\hline Municipalities & 2,94 \\
\hline EMAS Organizations & 2,10 \\
\hline Overall mean & $\mathbf{2 , 9 0}$ \\
\hline
\end{tabular}

One of the main functions of MCs is to support financially local organizations for spreading EMAS registrations. The efficacy of this action is considered to be rather low. It is noteworthy EMAS registered organizations assigned the lowest score because they have not received support for the maintenance and renewal of registration.

A negative feedback assigned the ability to create networks between organizations. The tools provided to share information and help communicate between different organizations were thus not perceived as effective (Table 10).

Table 10. Creation of a network among Clusters organizations

\begin{tabular}{|l|c|}
\hline \multicolumn{1}{|c|}{ Creation of a network among Clusters organizations } & Mean value \\
\hline Chambers of Commerce & 3,86 \\
\hline EMAS Organizations & 3,10 \\
\hline Municipalities & 3,06 \\
\hline ISO 14001 Organizations & 2,94 \\
\hline Overall mean & $\mathbf{3 , 2 4}$ \\
\hline
\end{tabular}

The MCs as coordinators of clusters environmental policies have to increase the level of knowledge of the certificate among local organizations. It has been asked to organizations if they were aware of EMAS Cluster Certificate release (Table 11). 
Table 11. Companies awareness of EMAS Cluster Certificate

\begin{tabular}{|l|c|}
\hline Company category & Level of awareness \\
\hline EMAS organizations & $72,72 \%$ \\
\hline ISO 14001 organizations & $50 \%$ \\
\hline
\end{tabular}

As showed in Table 11 not all organizations contacted are aware of EMAS Cluster Certificate. Just 50\% of organization certified ISO 14001 knew about it. This evidence is significantly negative because the interviewed organizations are the one interested in environmental issues due to the implementation of certified EMS.

\subsection{Survey findings: local authorities involvement}

As public authorities, Municipalities and Chambers of Commerce have among their tasks the coordination of the promotion of local sustainable development policies. For this reason they are more involved than other stakeholders' categories in the MCs activities. There were investigated the expectancy of public stakeholders on MCs actions. The results were compared with benefits actually found.

The municipalities have been asked to evaluate the effectiveness of EMAS Cluster Certificate in raising clusters' competitiveness. The average rating is 3,6. This value ranks between "cheap and quite effective". Only $22,2 \%$ felt the tool "effective or very effective".

As shown in Table 11, respondents perceived benefits due to the EMAS Cluster Certificate, the average value was 3,4. The improvement of environmental problems (4.1) and the improvement of the image of the territory present the highest level of perceived benefit (Table 12).

Table 12. MC activity - Municipalities main expectations compared with the obtained benefits

\begin{tabular}{|l|c|c|}
\hline Aspect & $\begin{array}{c}\text { Level of } \\
\text { relevance }\end{array}$ & $\begin{array}{c}\text { Level of obtained } \\
\text { benefits }\end{array}$ \\
\hline Strengthening Cluster reputation/ accountability & 4,89 & 4,28 \\
\hline Improvement of environmental performance of the cluster & 4,74 & 4,11 \\
\hline Economic development of the cluster & 4,37 & 3,17 \\
\hline Brokerage for funding and incentives & 4,32 & 2,94 \\
\hline Communication with citizens & 4,21 & 2,89 \\
\hline Promoting synergies with local institutions & 4,16 & 3,72 \\
\hline Involvement in local development projects & 4,06 & 3,00 \\
\hline Promoting synergy with local enterprises & 3,63 & 3,28 \\
\hline Increase competitiveness of the cluster & 3,63 & 3,00 \\
\hline
\end{tabular}




\begin{tabular}{|l|c|c|}
\hline Communication with organizations & 3,4 & 3,1 \\
\hline Creation of multi-stakeholder network & 3,00 & 3,06 \\
\hline Overall mean & $\mathbf{4 , 0 4}$ & $\mathbf{3 , 3 2}$ \\
\hline
\end{tabular}

Chambers of Commerce considered the increase in the competitiveness of enterprises to support the cluster and economic development of the territory as the main benefit coming out from the achievement of the EMAS Cluster Certificate. Both aspects are in fact considered as "important" and "very important" by $85,71 \%$ of the respondents.

The establishment of MCs aims for foster dialogue and collaboration among local stakeholders in order to promote sustainable development. For this reason MCs activity could be a suitable to amplify the action of Chambers of Commerce. Table 13 shows the benefits found and respondents have experienced an actual increase in the competitiveness of cluster enterprises and an improvement of cluster image due to obtaining EMAS Certificate. These aspects drove Chambers of Commerce decision of joining the Protocol.

Table 13. MC activity - Chamber of Commerce main expectations compared with the obtained benefits

\begin{tabular}{|l|c|c|}
\hline Aspect & Level of relevance & $\begin{array}{c}\text { Level of obtained } \\
\text { benefits }\end{array}$ \\
\hline Increase competitiveness of the cluster & 5 & 4,57 \\
\hline Economic development of the cluster & 4,71 & 4 \\
\hline Strengthening district reputation/accountability/image & 4,57 & 4,43 \\
\hline Promoting synergies with local stakeholders & 4,57 & 4 \\
\hline Improvement of environmental performance of the cluster & 4,43 & 3,57 \\
\hline Promoting synergies with local administrations & 4,29 & 3,86 \\
\hline Creation of multi-stakeholder network & 4 & 3,43 \\
\hline Involvement in local development projects & 4 & 3,57 \\
\hline Brokerage for funding and incentives & 3,71 & $\mathbf{3 , 9 3}$ \\
\hline Overall average & $\mathbf{4 , 3 7}$ \\
\hline
\end{tabular}

It has been asked to assess the efficacy of EMAS Cluster Certificate in advertising cluster production. The average rating corresponds to "reasonably well" (average 4,29). In addition, respondents also give a positive feedback on the ability of the instrument to rise cluster enterprises competitiveness (mean value 4,57). MCs numbered among their objectives the implementation of awareness and responsibility of local authorities about cluster environmental aspects. The ability to communicate is one of the major elements of MCs' action. Municipalities have been asked to express an opinion about the improvement of relations with the local groups of interest (Table 14). 
Table 14. Enhancement in managing local stakeholder relation (Municipalities)

\begin{tabular}{|l|c|}
\hline Stakeholder category & $\begin{array}{c}\text { Level of improvement in } \\
\text { stakeholder relation management }\end{array}$ \\
\hline Municipalities & 3,72 \\
\hline Higher-level Authorities & 3,56 \\
\hline Environmental Associations & 3,39 \\
\hline Enterprises & 3,28 \\
\hline Industrial Associations & 3,17 \\
\hline Trade Associations & 3,11 \\
\hline Citizens & 2,89 \\
\hline Trade Union & 2,72 \\
\hline Consumer Association & 2,56 \\
\hline Overall mean improvement & $\mathbf{3 , 2 0}$ \\
\hline
\end{tabular}

Probably, internal communication has increased more than communication outwards MCs. For this reason municipalities considered EMAS Cluster Certificate as a tool that allowed them to improve the relationship with other institutions rather than local stakeholders.

MCs actions should be aimed for improving relationship among local community groups and enterprises. Also the Chambers of Commerce were questioned on the possible improvement with stakeholders through MCs actions (Table 15).

Table 15. Enhancement in managing local stakeholder relations (Chambers of Commerce)

\begin{tabular}{|l|c|}
\hline Stakeholder category & $\begin{array}{c}\text { Level of improvement in stakeholder } \\
\text { relation management }\end{array}$ \\
\hline Public Administration & 4,86 \\
\hline Trade Associations & 4,71 \\
\hline Enterprises & 4,43 \\
\hline Industrial Associations & 4,43 \\
\hline Trade Unions & 4,43 \\
\hline Environmental Associations & 3,71 \\
\hline Consumer Associations & 3,14 \\
\hline Overall average & $\mathbf{4 , 2 4}$ \\
\hline
\end{tabular}


It was noted that activities carried out for the release of EMAS Cluster Certificate have "reasonably well" contributed to improve the relationship with local interest groups. The most significant improvements have concerned the relationship with the Public Administrations $(4,86)$ and trade associations $(4,71)$.

\section{Research findings}

The study findings can be summed up in strong and weak points of MCs actions for the application of EMAS scheme in clusters.

Weak points:

- The analysis showed a heterogeneous effects regarding MCs communication activity oriented to increase organizations awareness about EMAS Cluster Certificate. Not all organizations knew about the existence of EMAS Cluster Certificate. This is probably due to the scarcity of tools available to help networks creation among the different stakeholders categories and organizations. This situation has determined a lack of good practices and information sharing that would have fostered the awareness on the Certificate.

- The most critical aspect of MCs actions is related the diffusion of EMAS registrations among organizations. The study found that only a small fraction of organizations are registered compared to the total population of enterprises set in clusters. The main reason for this result should be found in the scarce financial support the companies and bureaucratic/administrative simplification to obtain EMAS registration.

\section{Strong points:}

- Respondents judged fairly positive MCs assistance in improving clusters environmental performances. In particular, Municipalities are the stakeholder category more satisfied by the effectiveness of this actions.

- MC intervention has perceived very positive concerning cluster image improvement. The results obtained by MC fulfilled the high expectations of the stakeholders. Of course, the most significant improvements were observed where MCs have been working since several years. That indicates that results of continues actions are appreciated by local stakeholders.

-The improvement of the relationship among local authorities and local stakeholders. Municipalities perceived low level of improvement instead Chambers of Commerce has considered the improvement of relationships as remarkable. In any case the improvement has been greater among institutions, it could be registered lower results in communications between among cluster organizations and citizens/consumers.

\section{Conclusions}

Italian experience of EMAS Cluster Certification represents an opportunity to promote participatory development mechanisms. This experience aligns with the international community orientation that emphasized the importance of implementing strategies for sustainable development involving the different categories of local stakeholders (f.e. Local Agenda 21). 
Because of their heterogeneous structure, formed by the agreement among clusters public and private entities, MCs are the appropriate bodies to implement mechanisms in order to involve all interest groups. The community orientation on EMAS cluster approach well suits the Italian productive structure. Italian industrial clusters (over 150 surveyed) are mainly composed by SMEs that thanks to the cluster approach can overcome structural difficulties which often prevent their adoption of EMS.

In fact, MCs can provide clusters companies with operational tools to reduce costs for implementing EMAS, such as the provision of common audit cycles, sharing documents (such as environmental policy and environmental statement) and free training of personnel. The survey showed that in clusters where these tools were available MCs actions to diffuse EMAS were perceived as more efficient.

MCs should strengthen their efforts in raising awareness among organizations in order to increase the uptake of EMAS Registration and they have to institute efficacy communication channels to increase knowledge in the certificate and give recognition for achieved results.

Several studies have stressed the benefits that organizations can get through their single registration. EMAS registered organizations can extend the authorizations for example the Integrated Pollution Prevention and Control (IPPC) can be renewed after 8 years instead of 5. Furthermore, the implementation of EMS improves business management systems that optimizes resources, reduces waste thus obtaining benefits in the medium term.

One of the most positive aspects of EMAS implementation in Italian clusters concerns the perception of an effective enhancement of these areas, both from local community and external stakeholders. MCs should cooperate with local organizations to create local marketing strategies in order to communicate effectively clusters environmental efforts [40]. Local marketing strategies can be an important support to overcome the economic crisis. Made in Italy and sustainability are factors with high business potential in particularly manifest in manufacturing clusters [41,42].

EMAS cluster certificate fully exploits that potential using cluster EMAS logo which vouch for credibility and concrete commitment of local stakeholders to implement sustainable policies. The logo allows to enhance and to positively differentiate local production.

MCs have a key role in creating mechanisms for communication and networking between various potentially interested parties (include examples such website, forums etc.).

Some Italian clusters benefitted from national and European funding to implement EMAS Cluster Certificate. The European Life found is dedicated to projects for innovation and management in the environmental field. Since 1992 European Union has co-financed 348 environmental innovation projects[43] providing $€ 348$ million (European Commission, Life Programme). Some co-financed projects are the PIONEER project (Paper Industry Operating in Network: en experiment for EMAS revision) in the paper clusters (Lucca, Italy ) and the ECCELSA project ("Environmental based on Cluster Compliance and Experiences Local SME- oriented Approaches") which involved 10 clusters located in five Italian regions [44].

MCs actions have the main purpose to improve of relations among the local stakeholders for this reason the survey involved both local authorities (Chambers of Commerce and Municipalities) and organizations with certified EMS (EMAS or ISO 14001). The Second Position Paper assigned MCs also the task to improve relationship among local organizations and citizens. Future investigation will consider this 
category of stakeholders. In particular, the objective will be to assess their knowledge about EMAS Certificate obtained by MC of the cluster they live and to investigate their perception on the usefulness of this instrument in improving environmental quality.

"The authors declare no conflict of interest".

\section{References}

1. Freeman, R.E. Strategic Management: A Stakeholder Approach, $1^{\text {st }}$ ed.; Pitman: Boston, US, 1984.

2. Clarkson, M. B. E. A Stakeholder Framework for Analysing and Evaluating Corporate Social Performance. Academy of Management Review, 1995, 20 (1), 92-117.

3. Delmas, M.; Toffel M.W. Stakeholders And Environmental Management Practices: An Institutional Framework. Business Strategy and the Environment 2004, 13, 209-222. Doi:10.1002/bse.409

4. Steurer, R.; Langer, M. E.; Konrad, A.; Martinuzzi, A. Corporations, Stakeholders and Sustainable Development I: A Theoretical Exploration of Business-Society Relations. Journal of Business Ethics 2005, 61, 263-281. Doi: 10.1007/s10551-005-7054-0

5. Stave, K. Participatory System Dynamics Modeling for Sustainable Environmental Management: Observations from Four Cases. Sustainability 2010, 2, 2762-2784 Doi:10.3390/su2092762

6. Sarkis, P.; Gonzalez-Torre, B.; Adenso-Diaz, B. Stakeholder pressure and the adoption of environmental practices: The mediating effect of training. Journal of Operations Management 2010, 28, 163-176. Doi:10.1016/j.jom.2009.10.001

7. Andersson, M.; Eriksson, O.; Borgstede (von), C. The Effects of Environmental Management Systems on Source Separation in the Work and Home Settings. Sustainability 2012, 4, 1292-1308. Doi:10.3390/su4061292

8. Delmas M.; Terlaak, A. Regulatory Commitment to Negotiated Agreements: Evidence from the United States, Germany, The Netherlands, and France. Journal of Comparative Policy Analysis 2002, 4, 5-29. Doi: 10.1023/A:1014965605401

9. Miles, M. P.; Covin, J. G. Environmental Marketing: A Source of Reputational, Competitive, and Financial Advantage. Journal of Business Ethics 2000, 23, 299-311. Doi:10.1023/A:1006214509281

10. Angell, L.C.; Klassen, R.D. Integrating environmental issues into the mainstream: an agenda for research in operations management. Journal of Operations Management 1999, 17 (5), 575-598

11. Reed, M. S. Stakeholder participation for environmental management: A literature review. Biological Conservation 2008, 141, 2417-2431. Doi: 10.1016/j.biocon.2008.07.01

12. Bäckstrand, K. Multi-Stakeholder Partnerships for Sustainable Development. European Environment 2006, 16, 290-306. Doi: 10.1002/eet.425

13. Michener, V.J. The Participatory Approach: Contradiction and Co-option in Burkina Faso. World Development 1998, 26 (12), 2105-2118. 
14. Stringer, L.C.; Prell, C.; Reed, M.S.; Hubacek, K.; Fraser, E.D.G.; Dougill, A.J. Unpacking "Participation" in the Adaptive Management of Social- ecological Systems: a Critical Review. Ecology and Society 2006, 11(2). Available online: http://www.ecologyandsociety.org/vol11/iss2/art39/ (accessed on 7th October 2013).

15. Selman, P. A sideways look at Local Agenda 21. Journal of Environmental Policy \& Planning 2010, 2, 39-53. Doi: http://dx.doi.org/10.1080/738552353

16. Osofsky, H. M. Defining Sustainable Development after Earth Summit 2002. Loy L.A. Int'L \& Comp. L. Rev.111 2003, $26 \quad$ (1), 111-126. Available online: http://digitalcommons.lmu.edu/ilr/vol26/iss1/6 (accessed on 1st October 2013).

17. Sancassiano W. Local agenda 21 in Italy: an effective governance tool for facilitating local communities' participation and promoting capacity building for Sustainability. Local Environment: The International Journal of Justice and Sustainability 2005, 10 (2), 189-200. Doi: http://dx.doi.org/10.1080/1354983052000330770

18. Owen, A. L.; Videras, J. Trust, Cooperation, and Implementation of Sustainability Programs: The Case of Local Agenda 21. Social Science Research Network. Available online at: http://ssrn.com/abstract=976074 (Accessed 1st Septemper 2013). Doi: http://dx.doi.org/10.2139/ssrn.976074

19. Mazzali, A.; Stocchiero, A. Cooperazione decentrata e governance dello sviluppo sostenibile Principi, strumenti e metodologie. Centro Studi Politiche Internazionali 2008, 12. Available online: http://www.cespi.it/pubblicazioni.html\#WP (accessed $3^{\text {rd }}$ September 2013)

20. Morrow, D.; Rondinelli, D. Adopting Corporate Environmental Management Systems: Motivations and Results of ISO 14001 and EMAS Certification. European Management Journal 2002, 20 (2), 159-171. PII: S0263-2373(02)00026-9

21. Hillary, R.; Thorsen, N. Regulatory and self-regulatory measures as routes to promote cleaner production. Journal of Cleaner Production 1999, 1 (11), 2-11. Doi:http://dx.doi.org/10.1016/S0959-6526(98)00030-4

22. Merli, R.; Ippolito, C.; Lucchetti M. C. Promoting Sustainability in Europe Through the EcoManagement and Audit Scheme (EMAS): Final Results of a Survey on Italian Organizations. In Proceedings of the 17th Annual Conference of the International Sustainable Development Research Society. New York, US, 8-10 November 2011.

23. J. Vernon, J.; Peacock, M.; Belin, A.; Ganzleben, C.; Candell, M.; Pedersen, E. R. Study on the Costs and Benefits of EMAS to Registered Organisations 2009. European Commission Draft Final Report by Milieu Ltd.and RPA Ltd. 2009 Study Contract No. 07.0307/2008/517800/ETU/G.2. Available on line: http://ec.europa.eu/environment/emas/pdf/news/costs_and_benefits_of_emas.pdf (accessed 12th July 2013)

24. Hillary, R. Environmental management systems and the smaller enterprise. Journal of Cleaner Production 2004, 12, 561-569. Doi: 10.1016/j.jclepro.2003.08.006

25. Beccattini, G. Modelli Locali di Sviluppo, $1^{\text {st }}$ Ed.; Il Mulino: Bologna, Italy, 1989 
26. Carminati, M.; Fortis, M. Industrial Clusters: The Economic Reality and Legislative Framework in Italy. Institute of European Study Cass \& Unicredit Group, 2008, 2. Available online: http://www.unicreditreviews.eu/ricercaavanzata/?search=1\&title=\&q=Titolo+articolo...\&authorname=carminati\&anno=\&edizione=\&aut ore $=($ accessed on 7 th October 2013).

27. Ricciardi, A. Le PMI Localizzate nei Distretti Industriali: Vantaggi Competitivi, Evoluzione Organizzativa, Prospettive Future. Quaderni di Ricerca sull'Artigianato, 2010, 54, 129-177. Available online: http://www.quaderniartigianato.com/wp-content/uploads/2011/05/4_A.RicciardiLe-PMI-localizzate-nei-distretti_N\%C2\%B054.pdf (accessed on 7th October 2013).

28. Carpinetti, L. C. R.; Gerolamo, M. C.; Cardoza Galdàmez, E. V. Continuous Innovation and Performance Management of SME Clusters. Creativity and Innovation Management 2007, 16 (4), 376-385. Doi: 0.1111/j.1467-8691.2007.00448.x

29. Daddi, T.; Testa, F.; Iraldo F. A cluster-based approach as an effective way to implement the Environmental Compliance Assistance Programme: evidence from some good practices. Local Environment, 2010, 15 (1), 72-82. Doi:72-82. 10.1080/13549830903406081

30. Daddi, T.; M. R. De Giacomo, F. Testa, S. Tessitore. Cluster Approach and Eco-Innovation in four Industrial Clusters of Tuscany Region (Italy). Environmental Economics 2012, 3 (2), 26-34. Available online: http://businessperspectives.org/journals_free/ee/2012/ee_2012_2_Daddi.pdf (accessed 3rd June 2013)

31. D'Amico, M.; Merli, R.; Preziosi, M. Indagine Conoscitiva sull'Attuazione di EMAS nei Distretti Italiani. ISPRA 2012, 166. ISBN: 978-88-448-0569-2. Available online: http://www.isprambiente.gov.it/it/pubblicazioni/rapporti/indagine-conoscitiva-sullattuazione-diemas-nei-distretti-italiani (accessed 23rd August 2013)

32. Schilirò, D. PMI e Distretti Industriali in Italia: una Sfida che Continua. Distretti e quarto capitalismo, 1st Ed.; Franco Angeli: Milano, Italy, 2009, pp.15-40.

33. Pastore P. Normativa e Governance dei distretti dell'Osservatorio. Osservatorio Nazionale Distretti Italiani 2010,1, 39-58. Available online: http://www.retecamere.it/download/270.html_ (accessed 18th June 2013)

34. Fortis, M. Il Made in Italy, 1st Ed.; Il Mulino: Bologna, Italy, 1998.

35. Battaglia, M.; Frey, M.; Datti, T. Industrial Clusters and Environmental Policies: New Tools and Territorial Management. Sustainable Development: Industrial Clusters and Environmental Management, Sustainable Development - Authoritative and Leading Edge Content for Environmental Management; Sime Curkovic, 1st Ed., 2010. Doi: 10.5772/45886. Available online: http://www.intechopen.com/books/sustainable-development-authoritative-and-leading-edgecontent-for-environmental-management/industrial-clusters-and-environmental-management (accessed 4th October 2013)

36. Iraldo, F.; Melis, M.; Tallone. Il ruolo degli Enti locali e delle Pubbliche Amministrazioni nello sviluppo degli schemi di certificazione ambientale volontaria EMAS e ISO 14001. IEFE 2010, Available online: http://www.iefe.unibocconi.it/wps/wcm/connect/Cdr/Centro_IEFEen/Home (accessed 1st July 2013) 
37. Frey, M.; Iraldo, F. A cluster-based approach for the application of EMAS. IEFE Working Paper Series 2007, 3, 1-15. Available online: http://ssrn.com/abstract=1031643 (accessed 12 September 2013)

38. Khanna, M.; Speir, C. Motivations for Proactive Environmental Management. Sustainability 2013, 5, 2664-2692. Doi:10.3390/su5062664

39. Cariani, R. Ecodistretti 2009. Made green in Italy: le politiche ambientali dei sistemi produttivi locali e dei distretti industriali, 1st Ed.; Franco Angeli: Milano, Italy, 2009.

40. Cancilia, E.; Iraldo, F. Competitività e ambiente: una prospettiva per il Made in Italy. ERVET 2010. Available online: www.ervet.it/htmlnew/news/ecomondo/Inter_0.pdf (accessed 2nd October 2013)

41. Pernigotti, D. EMAS negli ambiti produttivi omogenei: è attestazione o registrazione?. Ambiente \& Sicurezza 2008, 16, 28-32. Available online: http://www.aequilibria.com/userfiles/emas.pdf (Accessed $1^{\text {st }}$ September 2013)

42. Daddi, T.; Testa, F.; Irlado, F. A cluster-based Approach as an Effective Way to Implement Environmental Compliance Assistance Program: Evidence from some Good Practices. Local Environment 2010, 15 (1), 73-82. Doi: 10.1080/13549830903406081

(C) 2013 by the authors; licensee MDPI, Basel, Switzerland. This article is an open access article distributed under the terms and conditions of the Creative Commons Attribution license (http://creativecommons.org/licenses/by/3.0/). 